\section{GuIDELINES}

The Foundations have encouraged the participating institutions to seek the nominations of diverse candidates in their early or mid-careers who have demonstrated excellence in solving problems relevant to conserving biodiversity.At least one of the three awards will be to an individual working in a developing country. While the awards will fittingly recognize and reward leadership accomplishments, the essential goal of the programme is to find outstanding individuals whose work will be meaningfully advanced by the award.

The Foundations expect that nominees will represent an array of disciplines in the basic and applied sciences and other areas of study. These may include (but are not limited to) economics, history, computational biology, ethics, forestry, agronomy, veterinary medicine, public policy, and other traditional, combined, or emerging, fields which may prove germane to efforts to prevent biodiversity loss. It is the policy of the Foundations to make awards without regard to gender, race, ethnicity, age, citizenship, sexual orientation, or handicapping conditions.

Nominations, each with a supporting statement from the nominating institution, had to be received by the Foundations by May 1. By August 1 the Foundations will circulate to the panel members the assembled sets of nominee portfolios, including the nominees' resumés, brief statements of their three most significant publications or other accomplishments, and statements, of not more than two pages, explaining how their work would be advanced if they should receive the award.

On 29 September 1995 the panellists will meet in New York City to present and review all of the nominee portfolios, grading each for the final review of the top nine to twelve candidates. The following day, without disclosure of the order of ranking of the top candidates on the first day, the panellists will select the award finalist for each category. On the second day of panel proceedings, no panellist will be able to vote for the three nominees of his or her institution. Nominations will be received only from the participating institutions, and panel proceedings will be confidential.

The recipients will be announced bythe Foundations not later than 15 November 1995 . The awards will be payable in equal instalments over a period of three years beginning in 1996, or in such other manner as may be individually arranged with the agreement of the recipients. The Foundations have not announced any plans for a second round or possible further rounds* of awards, but are exploring the possibility of obtaining additional sponsors to expand the programme.

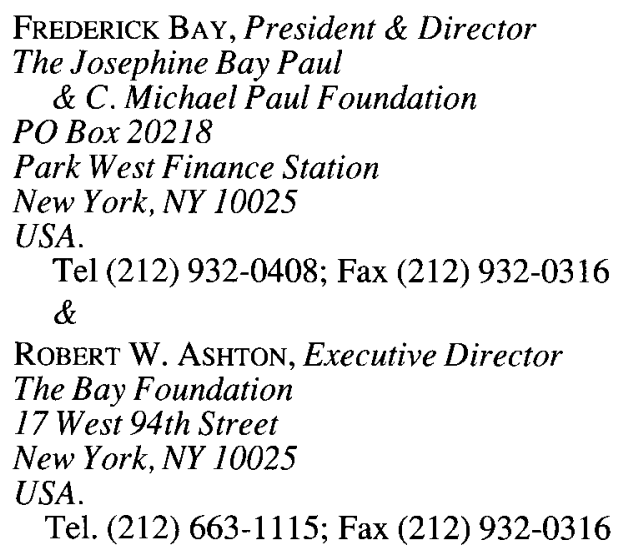

* In case no representative of either of the sponsoring Foundations corrects a proof of this account, we have to admit that the four words of text immediately preceding this asterisk were inserted by us without permission. The entire prospect of continuation of such good news in these times of desperate shortage of any funds for environmental/conservational work as this chance seemed to suggest was just too good to miss. - Ed.

PS. Proof was corrected by first-named Author without comment on this point, so we live in hope. - Ed.

\title{
WEC Honours Ciba-Geigy Limited at Eleventh Annual WEC Gold-medal Dinner
}

$\mathrm{C}$ liba-Geigy Limited has received the WEC 1995 Gold Medal for International Corporate Environmental Achievement from the World Environment Center (WEC). This tribute is presented annually to recognize a corporation with substantial international operations that has an outstanding and well-implemented world-wide environmental policy.

Dr Alex Krauer, Chairman of the Board and Chief Executive Officer (CEO) accepted the 1995 WEC Gold Medal on behalf of Ciba's 83,000 employees around the world. The award was presented by Gautam S. Kaji, Managing Director of the World Bank, at a dinner held in the National Building Museum in Washington, DC. The event was attended by over 500 leaders of industry, government, nongovernmental organizations, the diplomatic corps, the academic and scientific communities, and the media.

'We are pleased to honour Ciba-Geigy Limited for its corporate policy which requires an equal balance between long-term economic success, social responsibility, and responsibility for the environment', said Antony G. Marcil, President and CEO of WEC. 'Their efforts are borne out by the high level of personal environmental leadership that has typified Ciba's Chief Executive Officers, and the clear understanding that the successful implementation of Ciba's policies and principles is the obligation of all employees world-wide.'

Ciba-Geigy is a leading world-wide biological and chemical group, dedicated to satisfying needs in healthcare, agriculture, and industry, with innovative, valueadding, products and services. Under the topic of environmental responsibility, Ciba's corporate policy states that, '... respect for the environment must be part of everything we do. We design products and processes to fulfill their purpose safely and with as little environmental impact as possible. We use natural resources and energy in the best possible way, and reduce waste in all forms. It is our duty to dispose of all unavoidable waste by using state-of-the-art technology.'

Previous recipients of the WEC Gold Medal have been: S.C. Johnson and Son, Inc.; Xerox Corporation; The Procter \& Gamble Company; Rohm and Haas Company; IBM Corporation; The Dow Chemical Company; The British Petroleum plc; E.I. du Pont de Nemours \& Co.; Exxon Corporation; and 3M.

WEC, an independent, not-for-profit, non-advocacy organization, contributes to environmentally sustainable development world-wide by strengthening industrial and urban environment, health, and safety policy and practices. 
Through three complementary programmes - the International Environment and Development Service, the International Environment Forum, and the WEC Gold Medal for International Corporate Environmental Achievement - WEC serves as a bridge for the exchange of information and expertise among industry, government, and nongovernmental organizations. WEC is headquartered in
New York City but has offices also in Bangkok, Jakarta, Mexico City, Prague, and Washington, DC.

\section{ANN VENABLES}

World Environment Center

419 Park Avenue South, Suite 1800

New York

NY 10016, USA.

\section{European Nature Conservation Year 1995*}

E uropean Nature Conservation Year 1995 was officially launched on 31 January at the Palais de l'Europe, Strasbourg, France, the occasion being the session of the Parliamentary Assembly of the Council of Europe. Representatives of more than 40 European countries were present, together with numerous NGO representatives and members of parliament.

The ceremony began with speeches by Daniel Tarschys, Secretary General of the Council of Europe; Alecos P. Machaelides, Chairman of the Committee of Ministers; Miguel Angel Martínez, President of the Parliamentary Assembly; and Josef Hofmann, President of the Chamber

*Adapted from Naturopa Newsletter, Centre Naturopa, F-67075 Strasbourg Cedex, France.

of Local Authorities of the Congress of Local and Regional Authorities of Europe (CLRAE). All spoke highly of the involvement of the organs of the Council of Europe in this campaign. Jean-Marie Pelt, Chairman of the European Ecology Institute in Metz (France), in a lively and extremely relevant address, emphasized the importance of $\mathrm{Na}$ ture conservation outside protected areas.

The Alfred Toepfer special prize for conservation was presented to Robert Boote, who had presided over the first campaign for Nature conservation organized by the Council of Europe in 1970, by the Johan Wolfgang von Goethe Foundation whose headquarters is in Basle (Switzerland). An excerpt from the film Anima Mundi brought the ceremony to a close.

\section{World Oil Supply - More Than Enough?}

G lobal oil reserves have doubled since the oil crisis of 1973 and the world's oil reserves now guarantee oil supply for at least the next 44 years at today's production and real-price levels, in spite of a cumulative oil production of almost 500 thousand million barrels over the last 22 years (85\% of the proven reserves as declared in 1973). Actually, 'The world is running into oil, not out of it' said an energy expert at the International Energy Workshop held recently at IIASA. In the period between 1973 and 1995, reserves' discovery and development as well as the growing importance of indigenous and regional production have led to a decline in dependence on the oil reserves of the Middle East, though with two-thirds of the world's known reserves, that region could supply the world's demands for many years to come.

Oil exploration and exploitation have been less than systematic and intensive in the Middle East. Nevertheless, average annual additions to Middle Eastern reserves have almost matched average annual global use of oil at just over 20 thousand million barrels. Thus, this region alone continues to find enough oil on average each year to cover everyone's current annual needs on Earth. Even without discoveries of new reserves, we can expect current production levels for at least the next 100 years. However, a real oil price over 16 US $\$$ per barrel has greatly stimulated reserves' development and production expansion in other areas, such as the North Sea, offshore Mexico, Egypt, Southern Brazil, and parts of Australasia. 'Thus, much of the Middle East's proven oil reserves have no net present value', states Professor Peter Odell, of the London School of Economics and Erasmus University, Rotterdam.

As a consequence of these developments, there may be a potential regionalization of the global oil market. The world could become characterized by energy-trading blocs. As a result, the Middle East could have difficulty in attempts to increase its market share without running the risk of countervailing developments, such as most of the rest of the world continuing to secure the greater part of the energy it needs without recourse to more oil from the Middle East.

From OECD countries outside the US, the contribution of indigenous production to the total consumption has increased to over $35 \%$ today (from less than $14 \%$ in the
TABLE I

Estimated Global Oil Supplies (millions of b/d).

\begin{tabular}{lccc} 
& 1993 & $2000^{*}$ & $2010^{*}$ \\
\hline $\begin{array}{l}\text { World Total } \\
\quad \text { of which: }\end{array}$ & 65.1 & 70.1 & 76.4 \\
$\begin{array}{l}\text { Former Soviet Union, } \\
\text { Eastern Europe, and China }\end{array}$ & 11.1 & 12.7 & \\
$\begin{array}{l}\text { OPEC's present members } \\
\text { USA and Canada }\end{array}$ & 26.7 & 28.8 & 30.3 \\
Rest of OECD & 10.7 & 9.6 & 9.3 \\
Other LDCs & 5.6 & 5.8 & 5.6 \\
& 11.0 & 13.2 & 15.2
\end{tabular}

* Data for AD 2000 and 2010 are Professor Odell's forecasts.

1970s). Norway and Britain have become the world's fifth and sixth largest non-OPEC oil producers; and are ahead of all member countries of OPEC except Saudi Arabia and Iran. 'The expansion of northwest European output is highly likely to continue, so leading to a near $50 \%$ contribution of indigenous oil to Western Europe's total demand by [AD] $2000^{\prime}$, adds Professor Odell.

In the non-OPEC developing countries, known reserves were only some 35 thousand million barrels in 1973 . Between 1973 and 1994 these countries produced 55 thousand million barrels, yet their reserves are now over 96 thousand million barrels - enough for another 25 years at the present level of production. Oil imports of these same countries as a percentage of their production have fallen from almost $90 \%$ in 1974 to just $17 \%$ in 1994. Extent and intensity of oil exploration has been modest in this area, however, and these non-OPEC developing countries are the most significant in terms of production potential (Table I).

In the formerly centrally-planned economies, China is becoming relatively more important compared with the successor states of the former Soviet Union. China has succeeded in maintaining annual additions to reserves in excess of production, and still has a relatively high reserves-to-production ratio of almost 25 years.

ELISABETH KRIPPL \& CHRISTOPH SCHNEIDER Office of Public Information

International Institute of Applied

Systems Analysis (IIASA)

A-2361 Laxenberg, Austria. 